\title{
Strokes or Seizures, and Takotsubo Syndrome: A Possibly Underdiagnosed Association
}

\author{
John E. Madias ${ }^{a, b}$ \\ ${ }^{\mathrm{a}}$ Icahn School of Medicine at Mount Sinai, New York, and ${ }^{\mathrm{b}}$ Division of Cardiology, Elmhurst Hospital Center, \\ Elmhurst, N.Y., USA
}

Dear Sir

Practice of medicine in the future will increasingly depend on multidisciplinary groups of doctors caring for patients. This is currently being witnessed in the management of patients with malignancies by members of the emerging Cardio-oncology discipline. Considering the brain-heart pathophysiological link in Takotsubo syndrome (TTS) [1, 2], the need for a Neurocardiology field seems inevitable. These thoughts are prompted by the very interesting contribution of Blanc et al. [3], published in this journal, about 6 patients who suffered TTS in the setting of acute cerebral events (ACE), 4 following an ischemic stroke (IS) and 2 after epileptic events (EEs). As the authors state that ACE 'may be associated with massive catecholamine release' [3], it would have been contributory to have catecholamine

\section{References}

1 Samuels MA: Neurally induced cardiac damage. Definition of the problem. Neurol Clin 1993;11:273-292.

2 Samuels MA: The brain-heart connection. Circulation 2007;116:77-84.

3 Blanc C, Zeller M, Cottin Y, Daubail B, Vialatte AL, Giroud M, Béjot Y: Takotsubo cardiomyopathy following acute cerebral events. Eur Neurol 2015;74:163-168. blood levels in these patients, but this item was not included in the research variables examined in the RICO registry from which the authors derived their database. Of interest is that TTS was triggered by lesions in the insular cortex or posterior fossa [3], brain regions previously associated with brain-triggered injury to the heart $[1,2]$. The prevalence of TTS triggered by IS, EE or subarachnoid hemorrhage $(\mathrm{SH})$ must be higher than currently appreciated, considering that a large number of patients with TTS were detected in patients with SE who were prospectively and proactively evaluated with serial sophisticated echocardiography (ECHO) techniques $[4,5]$, particularly if one subscribes to the notion that TTS could present in atypical and/or milder forms [6]. Based on the above, one won- ders whether monitoring of patients with ACE (IS, EE and $\mathrm{SH}$ ) should have routine continuous electrocardiographic monitoring (arrhythmias, repolarization and depolarization abnormalities), an ECHO assessment and testing for a rise of troponins and brain natriuretic peptides, irrespective of their hemodynamic status. Such an undertaking will require not only mere implementation and ordering of the above modalities and diagnostic tests, but close collaboration of neurologists and cardiologists under the auspices of a hybrid field of Neurocardiology.

\section{Disclosure Statement}

The author reports no conflicts of interest.
4 Cinotti R, Piriou N, Launey Y, Le Tourneau T, Lamer M, Delater A, Trochu JN, Brisard L, Lakhal K, Bourcier R, Desal H, Seguin P, Mallédant $Y$, Blanloeil $Y$, Feuillet F, Asehnoune $K$, Rozec B: Speckle tracking analysis allows sensitive detection of stress cardiomyopathy in severe aneurysmal subarachnoid hemorrhage patients. Intensive Care Med 2015, Epub ahead of print.
5 Madias JE: Speckle tracking in patients with atypical Takotsubo syndrome: seek, and ye shall find! Intensive Care Med 2015, Epub ahead of print.

6 Madias JE: Forme fruste cases of Takotsubo syndrome: a hypothesis. Eur J Intern Med 2014;25:e47.

\section{KARGER}

E-Mail karger@karger.com www.karger.com/ene (c) 2016 S. Karger AG, Base

0014-3022/16/0752-0065\$39.50/0
John E. Madias, MD

Division of Cardiology

Elmhurst Hospital Center

79-01 Broadway, Elmhurst, NY 11373 (USA)

E-Mail madiasj@ nychhc.org 